\section{MRS-India Hosts Fifth Annual General Meeting}

The Hyderabad Local Chapter of MRS-I hosted the Fifth Annual General Meeting of the Materials Research Society of India at Research Centre Imarat, Hyderabad, February 7-9, 1994. More than 500 participants representing 145 organizations attended. Several distinguished overseas delegates including the presidents of the International Union of Materials Research Societies, the European Materials Research Society, and the Chinese Materials Research Society also made significant contributions to the meeting.

C.N.R. Rao, founder-president of MRSI, delivered the opening remarks, tracing the history of the Society since its inception in 1989. He noted the tremendous response that the Society has already received from the materials science community in India. In his inaugural address, Rao stressed the need to develop products for commercialization, citing as examples NFTDC, COMPROC, and ARC. Emphasizing the need to strengthen certain areas such as polymers, he also suggested that MRS-I organize a topical symposium on the subject.

M.S. Valiathan of SC-TIMST, Thiruvananthapuram, received the MRS-I 1994 Distinguished Materials Scientist of the Year Award in recognition of his outstanding contributions in materials science. In his honor lecture, "Heparin Bonding, Then and Now," Valiathan presented a fascinating view of heparin and its anticoagulant nature. The annual MRS-I/ICSC Superconductivity Awards were presented to S.K. Malik, TIFR, Bombay, and to P. Ganguly, NCL, Pune.

The inaugural session was followed by technical sessions featuring lectures by 18 MRS-I medal recipients and presentations by seven guest speakers from abroad.

\section{Lectures by Overseas Delegates}

"Silicon Photovoltaic Cells, An Alternative Approach," P. Siffert, honorary member of MRS-I and president of IUMRS.

"Challenge, Response and Serendipity in the Design of Materials," R.W. Cahn, honorary member of MRS-I, University of Cambridge, U.K.

"SiC: Present Progress and Future Promise," P. Glasow, president, E-MRS.

"Preparation and Tribological Properties of DLC Films by IBAD Process," Heng-de Li, honorary member of MRS-I and president, MRS-China.

"Development of Mechanical Properties of Single Crystal Superalloys: Present and Future Trends," T. Khan, ONERA, France.

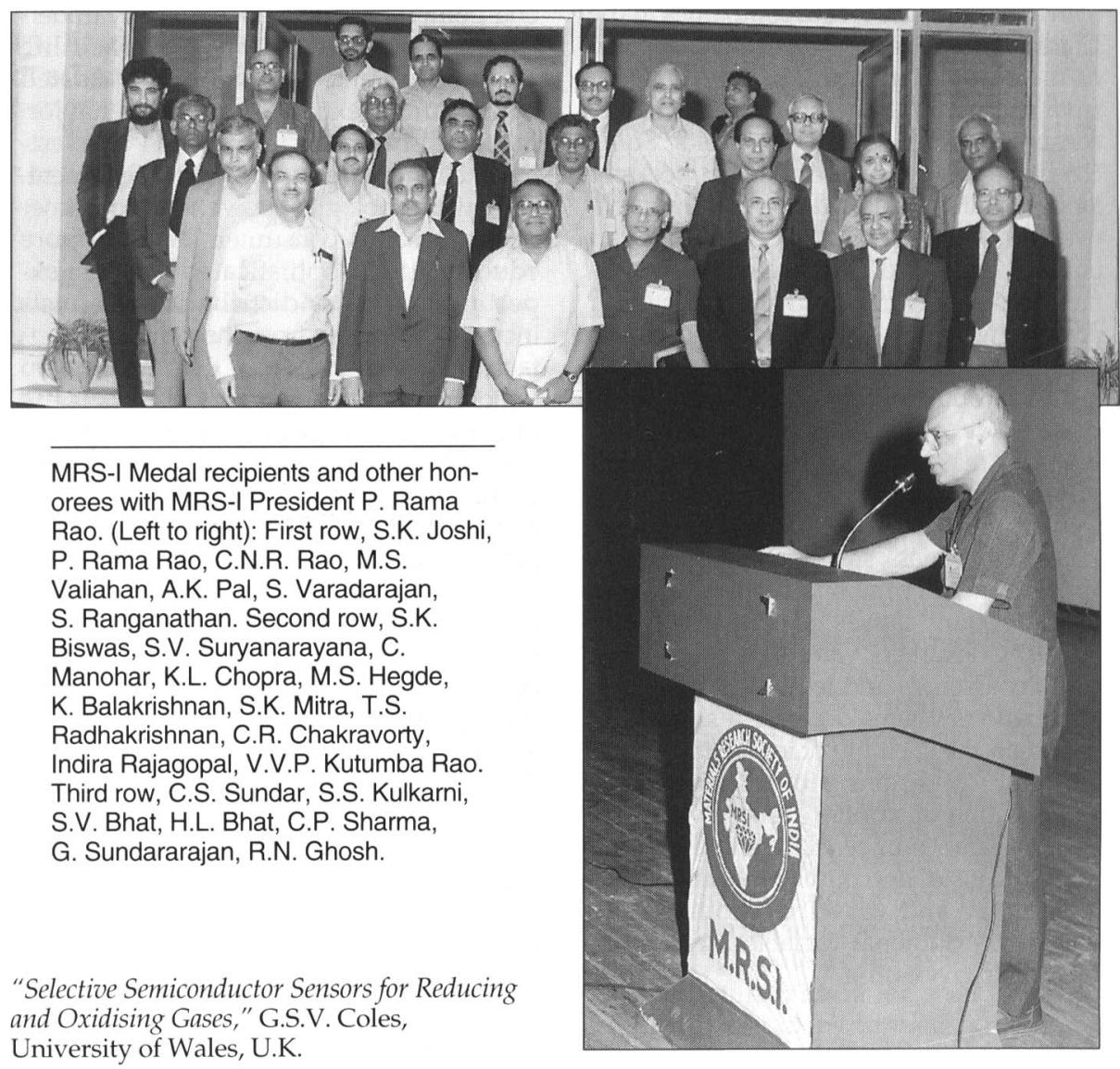

"Diamond Thin Films Growth by Chemical

Vapour Deposition," A.K. Kulkarni, Michigan Technological University, U.S.A.

\section{MRS-I Medal Lectures 1994}

"Structure Effect on Gas-Permeation

Characteristics in Polyacrylates," Sudhir S.

Kulkarni, NCL, Pune.

"Modelling the Hot Working Behaviour of

Metals - Some Emerging Trends," V.V.

Kutumba Rao, BHU, Varanasi.

"Surfactants: Materials for Interface Modification," C. Manohar,'BARC, Bombay.

"Tribology of a Piston Alloy," S.K. Biswas, IISc, Bangalore.

"Surface Engineering-Our Recent Experiences," Indira Rajgopal, NAL, Bangalore.

"Superconducting and Nonsuperconducting Oxide Multilayers," M.S. Hegde, IISc, Bangalore.

"Squids in Science and Technology," T.S. Radhakrishnan, IGCAR, Kalpakkam.

"Development of Al-Li Alloys," C.R.

Chakravorty, DMRL, Hyderabad.

"Growth and Characterisation of Some Novel Crystals for Nonlinear Optical Applications," H.L. Bhat, IISc, Bangalore.

"Magneto-Electric Interaction Phenomenon in Materials," S.V.Suryanarayana, OU,

Hyderabad.

"Grain Boundary Scattering in Polycrystalline Semiconductor Films," A.K. Pal, IASC,

Calcutta.
M.S.Valiathan, Distinguished Materials Scientist of the Year Award recipient, delivers his honor lecture on heparin bonding.

"Biomaterials - Role of Surface Modification," C.P. Sharma, SC-TIMST, Thiruvananthapuram.

"Modelling the High Temperature Creep Behaviour of Anisotropic Materials," R.N. Ghosh, NML, Jamshedpur.

"Trends in Corrosion Protection of Materials," K. Balakrishnan, CE-CRI, Karaikudi. "Carbon-Carbon Composite Product Development," G. Rohini Devi, DRDL, Hyderabad.

"Development and Use of High Technology Castables," S.K. Mitra, Tata Steel,

Jamshedpur.

"Positron Annihilation Spectroscopy in Materials Science," C.S. Sundar, IGCAR, Kalpakkam.

"Non-Resonant Radio Frequency and Microwave Response-A Novel Technique for the Characterisation of Superconducting Materials," S.V. Bhat, IISc, Bangalore.

S. RanGanathaN GENERAL SECRETARY MRS-INDIA 